\title{
Manganese ore tailing: Optimization of acid leaching conditions and recovery of soluble manganese
}

\author{
Olívia de Souza Heleno Santos*, Cornélio de Freitas Carvalho, Gilmare Antônia da Silva, \\ Cláudio Gouvêa dos Santos
}

Instituto de Ciências Exatas e Biológicas, Departamento de Química, Universidade Federal de Ouro Preto - UFOP, 35400-000 Ouro Preto, MG, Brazil

\section{A R T I C L E I N F O}

\section{Article history:}

Received 2 June 2014

Received in revised form

5 September 2014

Accepted 13 September 2014

Available online 3 October 2014

\section{Keywords:}

Manganese ore tailing

Multivariate experimental designs

Chitosan

\begin{abstract}
A B S T R A C T
Manganese recovery from industrial ore processing waste by means of leaching with sulfuric acid was the objective of this study. Experimental conditions were optimized by multivariate experimental design approaches. In order to study the factors affecting leaching, a screening step was used involving a full factorial design with central point for three variables in two levels $\left(2^{3}\right)$. The three variables studied were leaching time, concentration of sulfuric acid and sample amount. The three factors screened were shown to be relevant and therefore a Doehlert design was applied to determine the best working conditions for leaching and to build the response surface. By applying the best leaching conditions, the concentrations of 12.80 and $13.64 \% \mathrm{w} / \mathrm{w}$ of manganese for the global sample and for the fraction $-44+37 \mu \mathrm{m}$, respectively, were found. Microbeads of chitosan were tested for removal of leachate acidity and recovering of soluble manganese. Manganese recovery from the leachate was $95.4 \%$. Upon drying the leachate, a solid containing mostly manganese sulfate was obtained, showing that the proposed optimized method is efficient for manganese recovery from ore tailings.
\end{abstract}

๑) 2014 Elsevier Ltd. All rights reserved.

\section{Introduction}

Manganese consumption by the steel industry is considerably large, amounting to approximately $85 \%$ of the metal's production. The remainder is used in the production of electrolytic batteries, glass, fertilizers, animal feed or chemical inputs, among others. Worldwide, manganese ore production reached 14.5 Mt metal content in 2011, representing a production increase of approximately $16.6 \%$ over that of 2010 . The main producers are South Africa with over $23.4 \%$ of the world's production, followed by China with $19.3 \%$, Australia $16.5 \%$, Gabon $10.3 \%$, India $7.6 \%$, Ukraine $2.3 \%$ and Mexico $1.2 \%$, with other countries combined totaling 9.6\%. Brazil, which ranks fifth among the producing countries, accounts for $9.8 \%$ of the total produced in the world (DNPM, 2013).

The growing demand for manganese is leading to a rapid depletion of its natural sources, which has caused great interest in the recovery of this metal from both economic and environmental aspects. Industrial waste has caused great concern due to the environmental impact that its disposal and storage can create (Hilson, 2003). At the same time, sustainable development within

\footnotetext{
* Corresponding author. Tel.: +55 3134096376 .

E-mail address: santos.oliviash@yahoo.com.br (O.S.H. Santos).
}

the mining industry has been the target of both academic and industrial researches, fostering the adoption of measures to control and prevent pollution, in order to mitigate the damages caused by technology. One of such measures is the recycling of industrial waste by means of chemical and hydrometallurgical treatments so it can be reused in another industrial application (Azapagic, 2004).

There are several reports on manganese sulfate recovery from manganese ores by leaching with sulfuric acid (Zhang et al., 2010; Paixão et al., 1995). The great importance of manganese sulfate relates to its use as a raw material for the production of electrolytic cells, dyestuffs, pharmaceuticals, textiles and fertilizers (Nayl et al., 2011). However, leachates from this process has a low pH value and usually contains high impurity concentrations, such as $\mathrm{Al}, \mathrm{Co}, \mathrm{Cu}$, $\mathrm{Fe}, \mathrm{Ni}, \mathrm{Zn}$, etc., which are concomitantly solubilized with manganese (De Michelis et al., 2009). The most common methods found in literature to deal with the removal of impurities and recovery of manganese from solutions and leachates include solvent extraction (Martins et al., 2001), precipitation by hydroxides and carbonates (De Michelis et al., 2009), quicklime, sulfides and jarosite (Paixão et al., 1995) and adsorption methods in which chitosan micropellets are used to reduce the acidity and remove metals from the wastewater of coal mines (Fávere et al., 2007). 
Evaluation of the best conditions for improving the yield in manganese extraction has also been the focus of some investigations (Martins et al., 1999; Sharma, 1992). With this objective in mind, the application of multivariate experimental design methods involving suitable statistical techniques may be used with great benefit. Such tools are useful to assess the influence of several variables simultaneously in order to render the experiments more efficienct with a consequent optimization of the process. It results in more economy of the experimental process allowing for more objectivity of the conclusions (Calado and Montgomery, 2003). It is also possible to find the variables that really influence the system of the experimental domain investigated, and knowledge about some possible variable interactions, which are impossible through traditional methods (Lundstedt et al., 1998).

This paper describes some studies on manganese recovery in its sulfate salt state from wastes originated from the processing of manganese ores. Experimental conditions for leaching were optimized by multivariate experimental design approaches, where a full factorial design with central point was used for selection of the most significant variables. Subsequently a Doehlert design was applied using the most relevant variables in a larger number of levels. The best conditions for leaching manganese from the waste could, thus, be determined and the response surface could be obtained. Dilute sodium hydroxide and microbeads of low molecular weight chitosan were tested for removing the acidity from the leachate containing manganese sulfate.

\section{Materials and methods}

\subsection{Waste characterization}

\subsubsection{Sample preparation}

Tailings from manganese ore processing was kindly donated by Rio Doce Manganês (RDM) Company - Morro da Mina Unit, in Conselheiro Lafaiete (MG, Brazil). About $30 \mathrm{~kg}$ of waste were collected and sent to the laboratory.

Once in the laboratory, the sample was disaggregated, homogenized by the conical piles method and quartered in order to reduce the sample size for handling. Approximately $1.5 \mathrm{~kg}$ of dried sample were reserved for analysis, of which about $30 \mathrm{~g}$ were fractionated using a series of Tyler sieves ranging from 250 to $37 \mu \mathrm{m}$.

\subsubsection{Mineralogical characterization}

The global sample was oven-dried at $100 \pm 5^{\circ} \mathrm{C}$ for one hour and pulverized in an agate grail prior to X-ray analysis in a Shimadzu model XRD 6000 diffractometer, containing an iron tube. Peak interpretation was carried out using the Jade software.

\subsubsection{Chemical characterization}

After drying in the oven at $100 \pm 5{ }^{\circ} \mathrm{C}$ and digesting with concentrated hydrochloric acid, the sample was analyzed by inductively coupled plasma - atomic emission spectrometry (ICP$\mathrm{AES}$ ) in order to quantify $\mathrm{Al}, \mathrm{As}, \mathrm{Ba}, \mathrm{Be}, \mathrm{Bi}, \mathrm{Ca}, \mathrm{Cd}, \mathrm{Co}, \mathrm{Cr}, \mathrm{Cu}, \mathrm{Fe}, \mathrm{K}, \mathrm{Li}$, $\mathrm{Mg}, \mathrm{Na}, \mathrm{Mo}, \mathrm{Ni}, \mathrm{P}, \mathrm{Pb}, \mathrm{S}, \mathrm{Sb}, \mathrm{Sc}, \mathrm{Sr}, \mathrm{Th}, \mathrm{Ti}, \mathrm{V}, \mathrm{Y}, \mathrm{Zn}$ and $\mathrm{Zr}$. The analysis was performed with a model Ciros CCD Spectro spectrometer. Other analyses performed were the determination of loss on calcination (LOC) using an oven at $1000^{\circ} \mathrm{C}$ for $1 \mathrm{~h}$, determination of humidity using an oven at $100{ }^{\circ} \mathrm{C}$ for $2 \mathrm{~h}$, determination of the $\mathrm{MnO}_{2}$ content by oxidation-reduction volumetry by excess oxalate titration with potassium permanganate, and determination of $\mathrm{Si}$ as $\mathrm{SiO}_{2}$ by gravimetry (Alexeyev, 1979). The total manganese content was determined by melting the sample and the Volhard-Wolff method was used to determine the total soluble manganese content in the concentrated hydrochloric acid by titration with potassium permanganate in a zinc oxide buffer. All procedures were carried out in triplicate and the values taken as average.

\subsubsection{Thermal analysis}

Thermogravimetric analysis (TGA) was carried out on a model SDT 2960 TA Instruments device, with a heating rate of $10^{\circ} \mathrm{C} / \mathrm{min}$ starting at $20^{\circ} \mathrm{C}$ and under an oxidizing atmosphere with air flow.

\subsection{Leaching and multivariate experimental designs}

In order to recover the manganese present in the waste, a leaching process using sulfuric acid was carried out in order to obtain manganese as $\mathrm{MnSO}_{4}$. Leaching was applied to the global sample and for samples in two different granulometries $(-250+105$ and $-44+37 \mu \mathrm{m})$. Preliminary tests were performed in the laboratory in univariate form in order to select the factors to be studied. Based on these tests and in the literature (Martins et al., 1999; Momade, 1996), the evaluated variables were: concentration of $\mathrm{H}_{2} \mathrm{SO}_{4}$ solution ( $\mathrm{C}-\% \mathrm{w} / \mathrm{w}$ ); the leaching time ( $t$ - hours); and the amount of waste ( $w$ - grams). To study the factors affecting the leaching, a screening step was used involving a multivariate factorial design with central point for three variables at two levels $\left(2^{3}\right)$.

Based on the preliminary tests it was decided to fix the volume of $\mathrm{H}_{2} \mathrm{SO}_{4}$ solution in $10 \mathrm{~mL}$ and the stirring rate in $100 \mathrm{rpm}$. Fivefold experiments were performed at the central point in order to estimate the error. Table 1 shows the factors and levels used in a $2^{3}$ full factorial design. Tests were carried out randomly so that experimental errors due to non-controllable variables would also be randomly distributed throughout the procedure. The whole leaching process was performed under batching conditions.

From the results obtained with the factorial design with central point $2^{3}$, a Doehlert design with three factors was applied to establish the optimum working conditions. Table 2 presents the factors and levels used for the Doehlert design.

\subsection{Chemical characterization of leachate and manganese sulfate product}

New leaching tests were performed applying the best analysis conditions identified by the Doehlert design. The leachate obtained was submitted to $\mathrm{pH}$ measurement, and analyzed by atomic emission spectrophotometry with a plasma source for multielemental determination, while the manganese was determined by oxidation-reduction titration with potassium permanganate. A column with microbeads of low molecular weight chitosan (Sigma Aldrich) was used for neutralizing the leachate. For the neutralization of the leachate, $10 \mathrm{~mL}$ aliquots were eluted through the column containing chitosan. The $\mathrm{pH}$ of this neutralized leachate was measured and manganese was determined by oxidationreduction titration with potassium permanganate, to assess its recovery. Chitosan was regenerated by treatment with a $\mathrm{NaOH}$ solution $\left(0.1 \mathrm{~mol} . \mathrm{L}^{-1}\right)$. The neutralized leachate samples were dried on a hot plate fordetermining the amount of manganese sulphate produced.

Table 1

Variables and levels used in the $2^{3}$ full factorial design with central point for manganese leaching study.

\begin{tabular}{lllll}
\hline \multicolumn{2}{l}{ Variables } & \multicolumn{2}{l}{ Levels } \\
\cline { 3 - 5 } & & - & 0 & + \\
\hline $\mathrm{C}$ & $\mathrm{H}_{2} \mathrm{SO}_{4}$ concentration $(\% \mathrm{w} / \mathrm{w})$ & 9.8 & 31.9 & 54 \\
$\mathrm{t}$ & Leaching time $(\mathrm{h})$ & 1 & 3.5 & 6 \\
$\mathrm{w}$ & Amount of waste $(\mathrm{g})$ & 0.5000 & 1.0000 & 1.5000 \\
\hline
\end{tabular}


Table 2

Variables and levels used in the Doehlert design for manganese leaching study.

\begin{tabular}{|c|c|c|c|c|c|c|c|c|}
\hline Variables & & Levels & & & & & & \\
\hline \multirow[t]{2}{*}{$\mathrm{t}(\mathrm{h})$} & Coded & & -1 & -0.5 & 0 & 0.5 & 1 & \\
\hline & Uncoded & & 4 & 6 & 8 & 10 & 12 & \\
\hline \multirow[t]{2}{*}{$\mathrm{w}(\mathrm{g})$} & Coded & -0.866 & -0.577 & -0.289 & 0 & 0.289 & 0.577 & 0.866 \\
\hline & Uncoded & 0.1000 & 0.2502 & 0.3998 & 0.5500 & 0.7002 & 0.8498 & 1.0000 \\
\hline \multirow[t]{2}{*}{$\mathrm{C}(\% \mathrm{w} / \mathrm{w})$} & Coded & & & -0.817 & 0 & 0.817 & & \\
\hline & Uncoded & & & 4.9 & 9.8 & 14.7 & & \\
\hline
\end{tabular}

\section{Results}

\subsection{Tailing characterization}

\subsubsection{Granulometric analysis}

Particle size distribution of the dry sample submitted to sieving for 30 min showed that $86.6 \%$ of particles are smaller than $250 \mu \mathrm{m}$ (see in supplementary material).

\subsubsection{Mineralogical characterization}

Fig. 1 displays the diffraction pattern of manganese ore waste. Observe that the waste is composed mainly of the manganese minerals of rhodochrosite $\left(\mathrm{MnCO}_{3}\right)$ and spessartine $\left[\mathrm{Mn}_{3} \mathrm{Al}_{2}(-\right.$ $\left.\left.\mathrm{SiO}_{4}\right)_{3}\right]$. The sample consists of quartz $\left(\mathrm{SiO}_{2}\right)$, manganocummingtonite $\left[\mathrm{Mn}_{2}(\mathrm{Mg}, \mathrm{Fe}, \mathrm{Mn})_{5} \mathrm{Si}_{8} \mathrm{O}_{22}(\mathrm{OH})_{2}\right]$, birnessite $\left[\mathrm{Na}_{4}\left(\mathrm{MnO}_{2}\right)_{7} .9 \mathrm{H}_{2} \mathrm{O}\right]$, vermiculite $\left[\mathrm{Mg}_{3} \mathrm{Si}_{4} \mathrm{O}_{10}(\mathrm{OH})_{2}\right]$ and annite $\left[\mathrm{K}_{2}(\mathrm{Fe}, \mathrm{Mn}, \mathrm{Mg})_{5} \mathrm{Si}_{8} \mathrm{O}_{20}(\mathrm{~F}, \mathrm{OH})_{4}\right]$.

\subsubsection{Chemical characterization of the manganese ore waste}

The results for the concentration determinations of Al, As, Ba, Be, $\mathrm{Bi}, \mathrm{Ca}, \mathrm{Cd}, \mathrm{Co}, \mathrm{Cr}, \mathrm{Cu}, \mathrm{Fe}, \mathrm{K}, \mathrm{Li}, \mathrm{Mg}, \mathrm{Mn}, \mathrm{Na}, \mathrm{Mo}, \mathrm{Ni}, \mathrm{P}, \mathrm{Pb}, \mathrm{S}, \mathrm{Sb}, \mathrm{Sc}, \mathrm{Si}$, $\mathrm{Sr}$, Th, Ti, $\mathrm{V}, \mathrm{Y}, \mathrm{Zn}$ and $\mathrm{Zr}$ of the sample are shown in supplementary material.

The manganese content of the sample regarding pyrolusite $\left(\mathrm{MnO}_{2}\right)$ was $4.31 \pm 0.65 \%(\mathrm{w} / \mathrm{w})$. This result is allusive to the base oxide mineral birnessite, identified in the sample by XRD. This mineral, as well as rhodochrosite $\left(\mathrm{MnCO}_{3}\right)$ is soluble in hot hydrochloric acid. The total content of soluble manganese in the sample was $13.73 \%(\mathrm{w} / \mathrm{w})$ and the concentration of manganese in rhodochrosite can be determined by difference, corresponding to $9.4 \%(\mathrm{w} / \mathrm{w})$

The moisture content in the sample was $6.30 \pm 0.12 \%$. The result of the loss on ignition ( $\mathrm{LOI}$, at $1000{ }^{\circ} \mathrm{C}$ ) determination for the sample was $13.5 \pm 0.85 \%(\mathrm{w} / \mathrm{w})$. This result may be related to moisture and water loss because of crystallization, thermal decomposition of rhodochrosite $\left(\mathrm{MnCO}_{3}\right)$ and birnessite

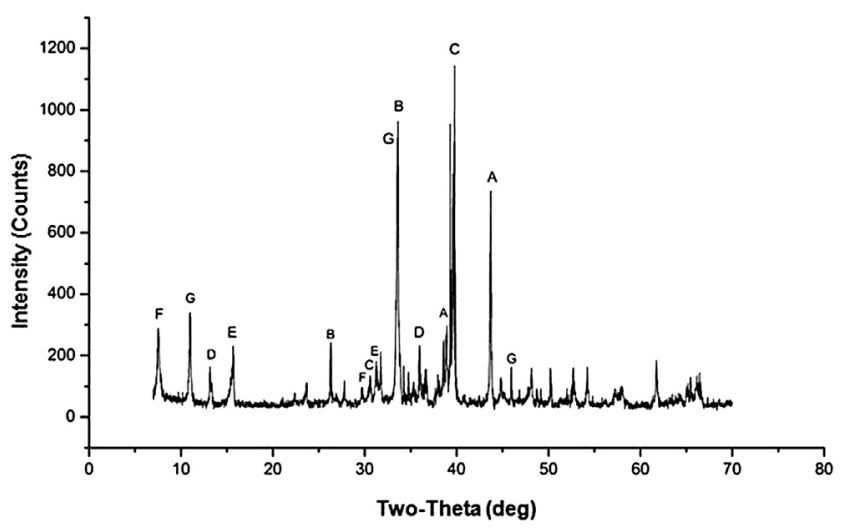

Fig. 1. Diffraction pattern of the manganese ore waste studied. The minerals identified in the sample were: A - Spessartine, B - Quartz, C - Rhodochrosite, D - Manganocummingtonite, $\mathrm{E}$ - Birnessite, $\mathrm{F}$ - Vermiculite and $\mathrm{G}$ - Annite.
$\left[\mathrm{Na}_{4}\left(\mathrm{MnO}_{2}\right)_{7} .9 \mathrm{H}_{2} \mathrm{O}\right]$, and also the loss of volatile components such as nitrogen, oxygen, hydrogen, among others.

The total manganese content of the sample after fusion with anhydrous sodium carbonate and of the soluble manganese in concentrated hydrochloric acid was $24.8 \%(\mathrm{w} / \mathrm{w})$ and $13.7 \%(\mathrm{w} / \mathrm{w})$, respectively. This difference can be explained by the different mineral phases in which the manganese is found in the tailing where the $24.8 \%$ content of manganese is due to the destruction of the crystal lattice by melting and the value of $13.7 \%$ manganese is due to the solubility of the mineral phases of rhodochrosite $\left(\mathrm{MnCO}_{3}\right)$, and birnessite $\left[\mathrm{Na}_{4}\left(\mathrm{MnO}_{2}\right)_{7} .9 \mathrm{H}_{2} \mathrm{O}\right]$ in hot concentrated hydrochloric acid.

\subsubsection{Thermal analyses}

Thermal analyses were carried out at a heating rate of $10^{\circ} \mathrm{C} / \mathrm{min}$ starting at $10^{\circ} \mathrm{C}$. Analyzes were conducted in an oxidizing atmosphere under air flow and the equipment employed was a SDT 2960 Simultaneous DTA-TGA from TA Instruments. Fig. 2 shows the TG curve for the sample of manganese ore waste.

According to Fig. 2 the weight loss from $20^{\circ} \mathrm{C}$ to around $200{ }^{\circ} \mathrm{C}$, corresponding to $0.9 \%$, may be associated with the elimination of moisture and loss of non-essential water. The $0.26 \%$ weight loss between 200 and $260{ }^{\circ} \mathrm{C}$ is assigned to the transformation of rodochrosite $\left(\mathrm{MnCO}_{3}\right)$ into pyrolusite $\left(\mathrm{MnO}_{2}\right)$. According to Shaheen and Selim (1998) the decomposition of $\mathrm{MnCO}_{3}$ into $\mathrm{MnO}_{2}$ has a first-loss of mass corresponding to $24.5 \%$ at approximately $300{ }^{\circ} \mathrm{C}$.

The amount of $\mathrm{MnCO}_{3}$ in the sample is $9.4 \% \mathrm{w} / \mathrm{w}$, therefore $1 \mathrm{~g}$ of sample of tailing is supposed to contain about $0.094 \mathrm{~g}$ of $\mathrm{MnCO}_{3}$ and $24.5 \%$ of this mass corresponds to $0.023 \mathrm{~g}$, giving a theoretical weight loss of $2.3 \%$ from the initial sample. Experimentally, a weight loss of $0.26 \%$ was found and this result might indicate that $\mathrm{MnCO}_{3}$ is associated with another mineral, being decomposed at temperatures higher than those cited in literature. The temperature difference observed for the onset of decomposition of the $\mathrm{MnCO}_{3}$ may be related to the complexity of the tailing and the different analysis conditions. Shaheen and Selim (1998) used Shimadzu DT40 in air atmosphere with a heating rate of $15^{\circ} \mathrm{C} / \mathrm{min}$ for analysis of a pure sample of $\mathrm{MnCO}_{3}$.

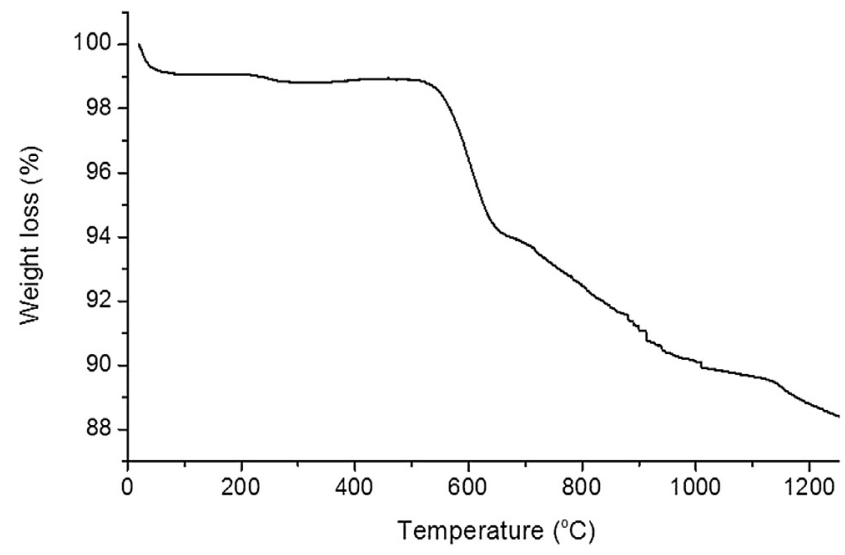

Fig. 2. Thermogravimetric analyses curve for the sample of manganese ore waste. 
A second peak $\left(598{ }^{\circ} \mathrm{C}\right)$ with mass loss of $4.9 \%$ can be related to the transformation of $\mathrm{MnO}_{2}$ into $\mathrm{Mn}_{2} \mathrm{O}_{3}$. The weight loss related to $\mathrm{MnO}_{2}$ is derived from the transformation into $\mathrm{MnCO}_{3}$ and also from the mineral birnessite $\left[\mathrm{Na}_{4}\left(\mathrm{MnO}_{2}\right)_{7} .9 \mathrm{H}_{2} \mathrm{O}\right]$, which was identified in the analysis of $\mathrm{X}$-ray diffraction. Birnessite is manganese mineral with an oxide phase which may have a thermal behavior similar to that of pyrolusite (Chitrakar et al., 2001; Franger et al., 2002). In addition to this, the transformation of the $\mathrm{MnCO}_{3}$ into $\mathrm{MnO}_{2}$ may still occur afterwards because it was incomplete at the earlier loss measurement.

The remaining weight losses (above $650{ }^{\circ} \mathrm{C}$ ) may be related to the transformation of $\mathrm{Mn}_{2} \mathrm{O}_{3}$ into $\mathrm{Mn}_{3} \mathrm{O}_{4}$ and also to changes in the other minerals present in the sample, particularly the hydrated silicates (Dose and Donne, 2011). Up to $1165^{\circ} \mathrm{C}$ there was a total loss of $11.6 \%$. This value can be an indirect measure of loss on ignition, which showed a total mass loss of $13.5 \%$. As for the loss on ignition, all the events of weight loss can be related to the release of volatile components such as nitrogen, oxygen, hydrogen, among others. This difference may be related to differences of the dynamic method of thermal analysis, in which the temperature varies with time, unlike the analysis of loss on ignition which is an isothermal method carried out at $1000^{\circ} \mathrm{C}$.

\subsection{Leaching of tailing with sulfuric acid and multivariate experimental designs}

\subsubsection{Screening step - 23 full factorial design with central point}

Table 3 presents the results found in the screening analysis using the $2^{3}$ full factorial design with five replicates in the central point for the global sample and for samples in two granulometries $(-250+105$ and $-44+37 \mu \mathrm{m})$.

Through the data presented in Table 3 it can be seen that the highest extraction of $\mathrm{Mn}^{2+}$ from the tailing was obtained for the fraction $-44+37 \mu \mathrm{m}$. The worst result was obtained for the fraction $-250+105 \mu \mathrm{m}$, which showed the lowest concentrations of $\mathrm{Mn}^{2+}$, while the extraction of $\mathrm{Mn}^{2+}$ for the global sample showed an intermediate result. These results can be explained by the larger contact surface of the finer fractions present in the global samples and the fraction $-44+37 \mu \mathrm{m}$ with $\mathrm{H}_{2} \mathrm{SO}_{4}$ solution used during the leaching process. In the fraction $-250+105 \mu \mathrm{m}$ predominate silicate phases which are insoluble in sulfuric acid.

One can also see that the highest concentrations found are related to essays involving longer times $(6 \mathrm{~h})$ and smaller mass $(0.5000 \mathrm{~g})$. The $p$ values for a significance level of 0.05 are provided

\section{Table 3}

Concentration of leached $\mathrm{Mn}^{2+}$ for the global sample and for two granulometries $(-250+105$ and $-44+37 \mu \mathrm{m})$ of waste, in the screening multivariate investigation.

\begin{tabular}{|c|c|c|c|c|c|c|}
\hline \multicolumn{7}{|c|}{$2^{3}$ Full factorial design } \\
\hline \multirow[t]{2}{*}{ Essay } & \multirow[t]{2}{*}{$\mathrm{t}$} & \multirow[t]{2}{*}{ C } & \multirow[t]{2}{*}{$\mathrm{w}$} & \multicolumn{3}{|c|}{ Response } \\
\hline & & & & Global & $-250+105 \mu \mathrm{m}$ & $-44+37 \mu \mathrm{m}$ \\
\hline 1 & 1 & 9.8 & 0.5000 & 8.30 & 6.57 & 11.11 \\
\hline 2 & 6 & 9.8 & 0.5000 & 9.04 & 8.12 & 13.21 \\
\hline 3 & 1 & 54 & 0.5000 & 7.69 & 5.53 & 11.72 \\
\hline 4 & 6 & 54 & 0.5000 & 9.87 & 6.63 & 12.57 \\
\hline 5 & 1 & 9.8 & 1.5000 & 5.43 & 4.90 & 9.13 \\
\hline 6 & 6 & 9.8 & 1.5000 & 8.13 & 6.71 & 11.43 \\
\hline 7 & 1 & 54 & 1.5000 & 4.62 & 4.76 & 9.35 \\
\hline 8 & 6 & 54 & 1.5000 & 7.32 & 7.89 & 10.73 \\
\hline 9 & 3.5 & 31.9 & 1.0000 & 9.14 & 7.97 & 12.52 \\
\hline 10 & 3.5 & 31.9 & 1.0000 & 9.03 & 7.39 & 12.52 \\
\hline 11 & 3.5 & 31.9 & 1.0000 & 8.96 & 7.59 & 12.31 \\
\hline 12 & 3.5 & 31.9 & 1.0000 & 8.81 & 7.12 & 12.56 \\
\hline 13 & 3.5 & 31.9 & 1.0000 & 9.23 & 7.20 & 12.30 \\
\hline
\end{tabular}

$t=$ time in hours, $C=$ concentration of $\mathrm{H}_{2} \mathrm{SO}_{4}$ solution $(\% \mathrm{w} / \mathrm{w}), w=$ amount of waste in grams and Response $=$ Concentration of leached $\mathrm{Mn}^{2+}(\% \mathrm{w} / \mathrm{w})$. in the supplementary material. Variables that showed greater significance were the amount of waste and shaking time.

After completion of the screening procedure, applying the $2^{3}$ full factorial design with central point, the variables which represented the most significant factors, i.e., the variables of leaching time and tailing weight were studied in a larger number of levels by the Doehlert design. As the resulted model presented lack of fit by the variance analysis (ANOVA) ( $p<0.05$ in a confidence level of 95\%), all variables were again evaluated by the surface response methodology.

\subsubsection{Optimization step - Doehlert design with central point}

From the results of the full factorial design, the surface response surface methodology was applied using the Doehlert matrix, aiming to optimize the independent variables (amount of waste, concentration of sulfuric acid solution and stirring time). The choice of the studied levels of each variable was based on the responses obtained by the screening step. In the Doehlert design, the $-250+105 \mu \mathrm{m}$ fraction of the waste was not studied since it presented the smallest amount of leached $\mathrm{Mn}^{2+}$ by the $2^{3}$ full factorial design. Table 4 presents the results of the leaching tests carried out by applying the Doehlert design to the global sample and the $-44+37 \mu \mathrm{m}$ fraction.

The best response, i.e., the highest concentration of $\mathrm{Mn}^{2+}$ ions leached was obtained in the essay 7 ( $10 \mathrm{~h}, 0.1000 \mathrm{~g}$ of sample and $\mathrm{H}_{2} \mathrm{SO}_{4}$ solution $9.8 \% \mathrm{w} / \mathrm{w}$ ), followed by essay 12 ( $8 \mathrm{~h}, 0.2502 \mathrm{~g}$ of sample and $\mathrm{H}_{2} \mathrm{SO}_{4}$ solution $14.7 \% \mathrm{w} / \mathrm{w}$ ) for the global and the $-44+37 \mu \mathrm{m}$ fraction samples (Table 4).

In this way, the optimum conditions for leaching manganese from tailing were defined as: $0.1000 \mathrm{~g}$ of sample to $10 \mathrm{~mL}$ of a $9.8 \%$ $\mathrm{w} / \mathrm{w} \mathrm{H}_{2} \mathrm{SO}_{4}$ solution, stirring for $10 \mathrm{~h}$ at $100 \mathrm{rpm}$. The results obtained in the leaching process by the Doehlert design were submitted to ANOVA for the global sample and the $-44+37 \mu \mathrm{m}$ fraction (see in supplementary material).

From the variance analysis, for both the global sample and its $-44+37 \mu \mathrm{m}$ fraction (see in supplementary material), the ratio between the quadratic average of the regression and the quadratic average of the residue $\left(\mathrm{F}_{\text {calc. }}\right)$, when compared to the theoretical distribution $F$ ( $\left.F_{\text {tab. }}\right)$, shows the statistical significance of the regression; in this case the regression is statistically significant

Table 4

Concentration of leached $\mathrm{Mn}^{2+}$ from the global sample and the $-44+37 \mu \mathrm{m}$ fraction, in the optimization study of manganese leaching.

\begin{tabular}{|c|c|c|c|c|c|}
\hline \multicolumn{6}{|c|}{ Doehlert design } \\
\hline \multirow[t]{2}{*}{ Essay } & \multirow[t]{2}{*}{$\mathrm{t}$} & \multirow[t]{2}{*}{ w } & \multirow[t]{2}{*}{$\mathrm{C}$} & \multicolumn{2}{|c|}{ Response } \\
\hline & & & & Global & $-44+37 \mu \mathrm{m}$ \\
\hline 1 & 12 & 0.5500 & 9.8 & 10.05 & 11.40 \\
\hline 2 & 10 & 10.000 & 9.8 & 8.75 & 12.03 \\
\hline 3 & 10 & 0.7002 & 14.7 & 9.26 & 12.13 \\
\hline 4 & 4 & 0.5500 & 9.8 & 9.36 & 10.5 \\
\hline 5 & 6 & 0.1000 & 9.8 & 11.77 & 13.29 \\
\hline 6 & 6 & 0.3998 & 4.9 & 9.48 & 11.12 \\
\hline 7 & 10 & 0.1000 & 9.8 & 12.86 & 13.85 \\
\hline 8 & 10 & 0.3998 & 4.9 & 10.47 & 11.56 \\
\hline 9 & 6 & 10.000 & 9.8 & 8.81 & 11.63 \\
\hline 10 & 8 & 0.8498 & 4.9 & 8.92 & 11.49 \\
\hline 11 & 6 & 0.7002 & 14.7 & 9.55 & 11.67 \\
\hline 12 & 8 & 0.2502 & 14.7 & 12.80 & 13.64 \\
\hline 13 & 8 & 0.5500 & 9.8 & 10.89 & 12.03 \\
\hline 14 & 8 & 0.5500 & 9.8 & 10.45 & 12.02 \\
\hline 15 & 8 & 0.5500 & 9.8 & 10.40 & 12.25 \\
\hline 16 & 8 & 0.5500 & 9.8 & 10.62 & 12.17 \\
\hline 17 & 8 & 0.5500 & 9.8 & 10.53 & 12.25 \\
\hline
\end{tabular}

$t=$ time $(\mathrm{h}), \mathrm{C}=$ concentration of $\mathrm{H}_{2} \mathrm{SO}_{4}$ solution $(\% \mathrm{w} / \mathrm{w}), \mathrm{w}=$ amount of waste $(\mathrm{g})$ and Response $=$ Concentration of leached $\mathrm{Mn}^{2+}(\% \mathrm{w} / \mathrm{w})$. 
( $F_{\text {calc. }}>F_{t a b}$.). It was also noted that the lack of fit is not significant since the $p$ value is greater than the significance level at 0.05 .

The data were plotted in graph form for comparison with the values estimated by the models. It is observed that the empirical models proposed, which relate the operational variables investigated and the experimental responses measured, are suitable for explaining the leaching process of both the global sample (Fig. 3A) and its $-44+37 \mu \mathrm{m}$ fraction (see in supplementary material), revealing good agreement. For the global sample, the determination coefficient $\left(R^{2}\right)$ was 0.9845 , indicating that only $1.55 \%$ of the total variation around the average is not explained by regression. For the $-44+37 \mu \mathrm{m}$ fraction, the $R^{2}$ value was 0.9951 , indicating that only $0.49 \%$ of the total variation around the average is not explained by regression. Analysis of the residual plots for the global sample (Fig. 3B) and its $-44+37 \mu \mathrm{m}$ fraction (see in supplementary material) also confirms that there was no lack of fit of the models due to the random distribution of residues with low magnitudes when compared to estimated values.

The response surfaces of the Doehlert design in the optimization of the leaching process of $\mathrm{Mn}^{2+}$ can be seen in Fig. 4 for the global sample and in the supplementary material for its $-44+37 \mu \mathrm{m}$ fraction.

It is clear that the influence of the mass in the leaching process occurs in such a way that the smaller the mass, the greater the

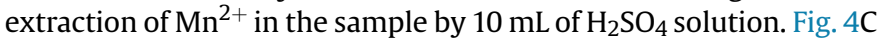
shows the interaction of the concentration of $\mathrm{H}_{2} \mathrm{SO}_{4}$ with the amount of waste as the most significant. This is followed by the interaction of $\mathrm{H}_{2} \mathrm{SO}_{4}$ solution with time (Fig. 4A), which was less significant because the concentration of leached $\mathrm{Mn}^{2+}$ was lower than the others. The same behavior can be observed for the leaching of the $-44+37 \mu \mathrm{m}$ fraction (see in supplementary material). It is also noted that the amount of leached manganese is larger for a particle size of $-44+37 \mu \mathrm{m}$, compared to the results obtained for the global sample, since it has greater tailing particle surface contact with the sulfuric acid solution.

\subsubsection{Chemical characterization of leachate and the resulting manganese sulfate}

Upon completion of the leaching of manganese in the waste with a solution of $\mathrm{H}_{2} \mathrm{SO}_{4}$, a leachate containing manganese sulfate with a $\mathrm{pH}$ of approximately 1.0 was obtained. Results from the chemical characterization of the leachate are provided as supplementary material.
The extremely acid pH due to sulfuric acid excess prevented the leachate from being dried and a neutralizing step for the leachate proved necessary.

Since the desired product is manganese sulfate, neutralization with $\mathrm{NaOH}$ was not possible due to the precipitation of manganese oxide starting from $\mathrm{pH} 2$.

Some studies have shown the effectiveness of chitosan in removing acidity and some metal ions, particularly iron (III), from wastewater (Ngah et al., 2005). Being a weak base ( $\mathrm{pK}_{\mathrm{a}} 6.5$ ), chitosan was inefficient to remove manganese and prevented the precipitation of manganese at $\mathrm{pH}$ values below 8 . In this work, this property became important, since keeping the manganese in solution was an objective throughout.

For purification and neutralization of the leachate, microbeads of chitosan were used. Chitosan is a copolymer of 2 -amino- $\beta(1-4)$ 2 -deoxy-D-glucopyranose and 2-acetamido- $\beta(1-4)-2$-deoxy-Dglucopyranose prepared by deacetylation of chitin - a biopolymer present in fungi and crustacean shells (see the chitosan structure in the supplementary material) (Fávere et al., 2007).

The mechanism involved in the removal of $\mathrm{H}^{+}$ions using chitosan microbeads can be seen in Equation (1):

$$
\begin{aligned}
& \left.2 \mathrm{H}^{+}+\mathrm{SO}_{4}^{2-}\right\} 2 \mathrm{R} \cdot \mathrm{NH}_{2} \rightarrow 2 \mathrm{R} \cdot \mathrm{NH}_{3}\left\{\mathrm{SO}_{4}^{2-}\right. \\
& \mathrm{R}=\text { polymer chain }
\end{aligned}
$$

The amount of manganese recovered and the final $\mathrm{pH}$ of the solution for the leached samples after running through the column containing chitosan are shown in supplementary material.

Chitosan was effective for both the removal of acidity and the recovery of manganese. In the manganese sulfate leachate, the $\mathrm{pH}$ achieved by passing the sample through the column containing chitosan was 7.3, approximately, while the average of manganese recovery was $95.4 \%$.

The maximum amount of leached eluted from the column containing $10 \mathrm{~g}$ of chitosan was $25 \mathrm{~mL}$ to a final $\mathrm{pH}$ value of 7 . Therefore $1 \mathrm{~kg}$ of chitosan microbeads would be able to raise the $\mathrm{pH}$ of $2.5 \mathrm{~L}$ of the leachate from 1.0 to 7.0, which corresponds to a neutralization capacity of $0.25 \mathrm{~mol}$ of $\mathrm{H}^{+}$per $\mathrm{kg}$ of microbeads.

After neutralization of the solution, the solid obtained was weighed and Mn was quantified. The recovery of manganese by leaching utilizing essay 7 conditions of the Doehlert design was 95.4\%. The mass of solid obtained containing manganese sulfate was $0.0972 \mathrm{~g}$. When considering the extraction of $13 \% \mathrm{w} / \mathrm{w}$ of
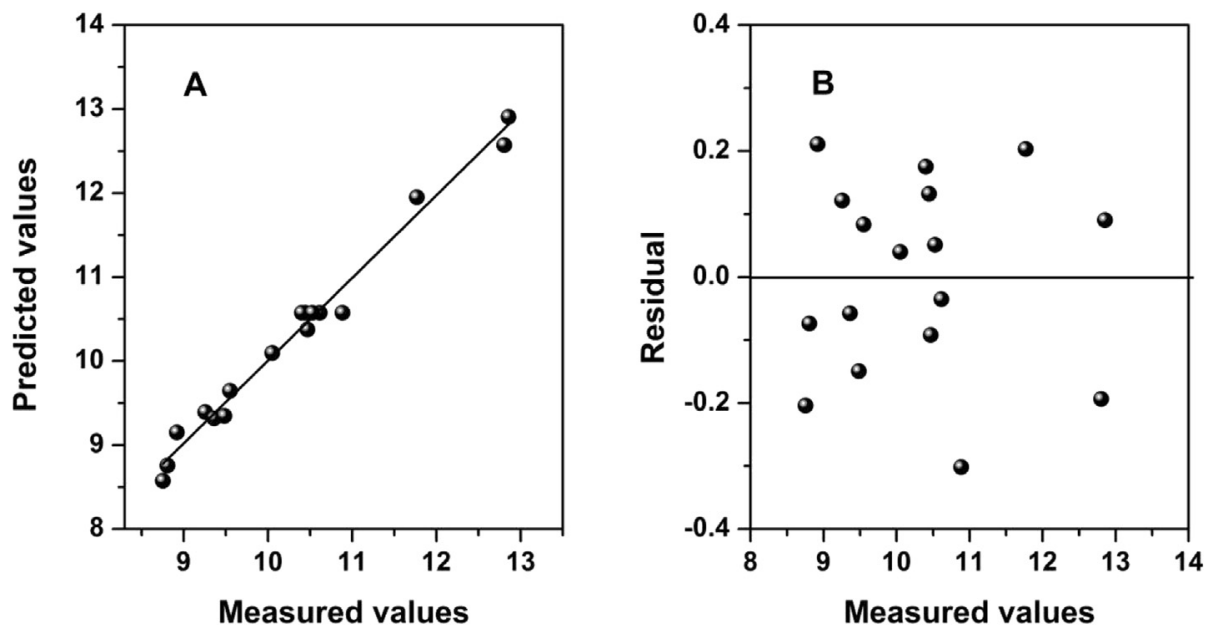

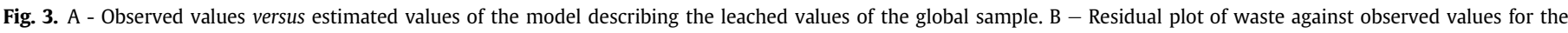
leaching process of the global sample. 

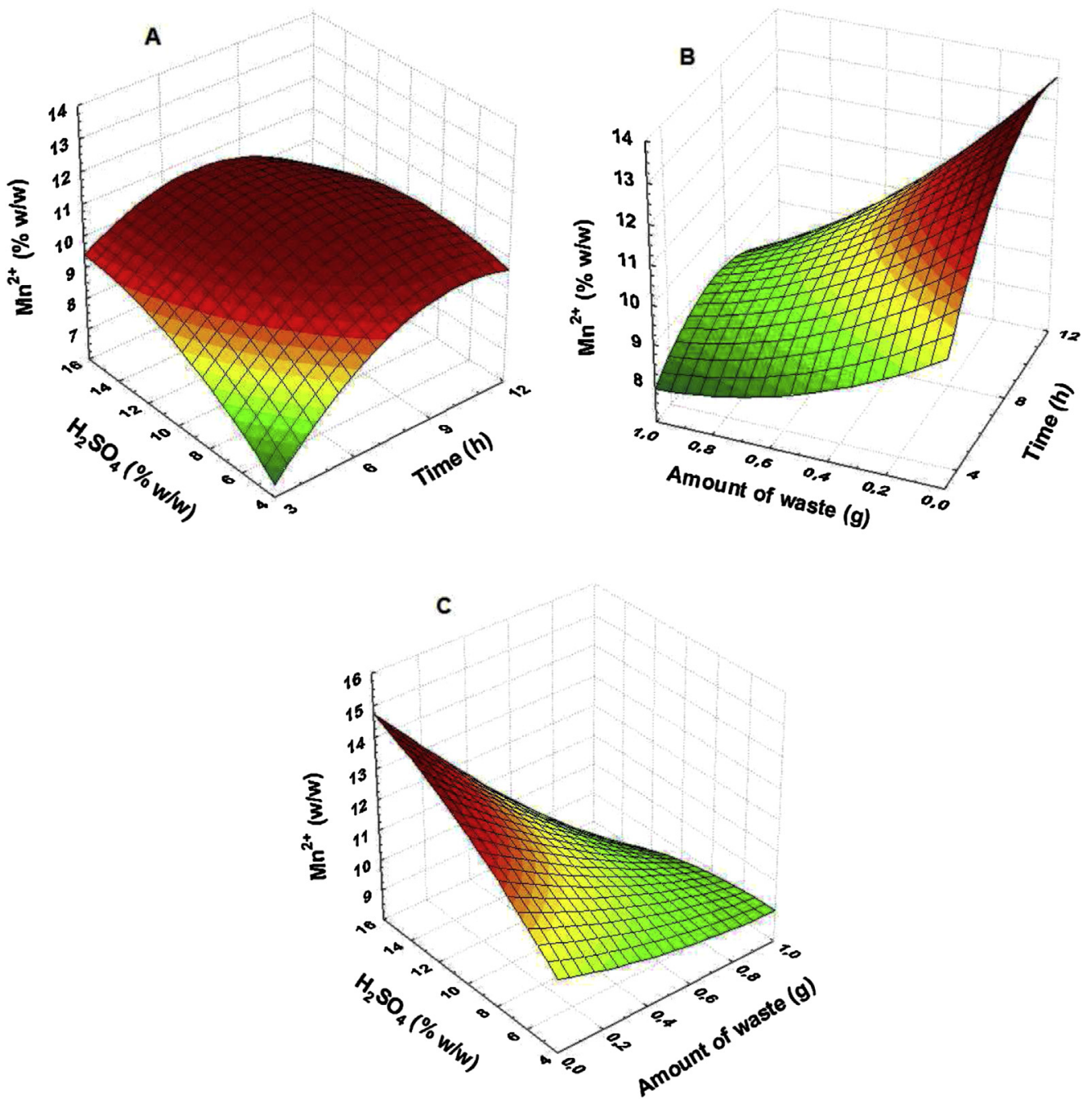

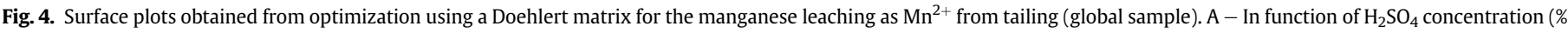
$\mathrm{w} / \mathrm{w}$ ) and time (h); B - In function of time (h) and amount of waste (g) and C - In function of $\mathrm{H}_{2} \mathrm{SO}_{4}$ concentration (\% w/w) and amount of waste (g).

manganese, $0.1000 \mathrm{~g}$ of sample would theoretically yield $0.0360 \mathrm{~g}$ of manganese sulfate. Apart from manganese sulfate, the $0.0972 \mathrm{~g}$ of solids produced contain other elements ( $\mathrm{Ca}, \mathrm{K}$ and $\mathrm{Mg}$ ); however their quantification gave incongruous values.

The manganese sulfate obtained by the procedures described in this article could find many applications, such as those in the fertilizer industry. In order to improve the quality of the product obtained, methods for selective precipitation of contaminants are currently being investigated.

\section{Conclusion}

Manganese ore waste is composed of the minerals rhodochrosite $\left(\mathrm{MnCO}_{3}\right)$, birnessite $\left[\mathrm{Na}_{4}\left(\mathrm{MnO}_{2}\right)_{7} .9 \mathrm{H}_{2} \mathrm{O}\right]$ and spessartine $\left[\mathrm{Mn}_{3} \mathrm{Al}_{2}(-\right.$ $\left.\mathrm{SiO}_{4}\right)_{3}$ ]. The total manganese content present in the waste is $24.76 \%$, from which $13.71 \%$ correspond to rhodocrosite and birnessite, which are soluble in sulfuric acid. The application of multivariate experimental designs was of great importance for the determination and optimization of experimental conditions for leaching the waste with sulfuric acid. The application of the full factorial design was suitable for the screening of variables; the most significant being the amount of waste and the sulfuric acid. Through the Doehlert design, it was possible to optimize the manganese leaching allowing determination of the optimum working conditions, which were: stirring for
$10 \mathrm{~h}$, sulfuric acid concentration of $9.8 \% \mathrm{w} / \mathrm{w}$ and amount of waste $0.1000 \mathrm{~g}$. The variables of sulfuric acid volume and stirring rate were set at $100 \mathrm{rpm}$ and $10 \mathrm{~mL}$, respectively. The use of chitosan microbeads for neutralizing the $\mathrm{pH}$ of the leachate containing manganese sulfate showed great efficiency. Since the $\mathrm{pH}$ of the final solution of manganese sulfate was approximately 7.0 and the average recovery of manganese was $95.5 \%$, the leaching of $0.1000 \mathrm{~g}$ of manganese ore waste with sulfuric acid produced $0.0972 \mathrm{~g}$ of a solid containing manganese sulfate and other elements such as $\mathrm{Ca}$, $\mathrm{Mg}$ and $\mathrm{K}$, which can be precipitated as sulfate, demonstrating the great efficiency of the developed and optimized method for recovery of manganese ore waste.

\section{Acknowledgments}

The authors thank the Federal University of Ouro Preto (MG, Brazil) for financing studies and Rio Doce Manganês (RDM) Company - Morro da Mina Unit, in Conselheiro Lafaiete (MG, Brazil) for providing the waste.

\section{Appendix A. Supplementary data}

Supplementary data related to this article can be found at http:// dx.doi.org/10.1016/j.jenvman.2014.09.020. 


\section{References}

Alexeyev, V., 1979. Quantitative Analysis. Mir Publishers, Moscow.

Azapagic, A., 2004. Developing a framework for sustainable development indicators for the mining and minerals industry. J. Clean. Prod. 6, 639-662.

Calado, V., Montgomery, D.C., 2003. Planejamento de experimentos usando Statistica. E-Papers Serviços Editoriais, Rio de Janeiro.

Chitrakar, R., Kanoh, H., Kim, Y., Miyai, Y., Ooi, K., 2001. Synthesis of layered-type hydrous manganese oxides from monoclinic-type $\mathrm{LiMnO}_{2}$. J. Solid. State Chem. 160, 69-76.

De Michelis, I., Ferella, F., Beolchini, F., Vegliò, F., 2009. Reducing acid leaching of manganiferous ore: effect of the iron removal operation on solid waste disposal. Waste Manage. 29, 128-135.

Departamento Nacional de Produção Mineral (DNPM). Sumário Anual 2012. http:// www.dnpm.gov.br. Accessed: July, 2013.

Dose, W.M., Donne, S.W., 2011. Manganese dioxide structural effects on its thermal decomposition. Mater. Sci. Eng. 176, 1169-1177.

Fávere, V.T., Laus, R., Geremias, R., Vasconcelos, H.L., Laranjeira, M.C.M., 2007. Reduction of acidity and removal of metal ions from coal mining effluents using chitosan microspheres. J. Hazard. Mater. 149, 471-474.

Franger, S., Bach, S., Farcy, J., Ramos, J.P.P., Baffier, N., 2002. Synthesis. structural and electrochemical characterizations of the sol-gel birnessite $\mathrm{MnO}_{1.84} \cdot 0.6 \mathrm{H}_{2} \mathrm{O}$. J. Power Sources 109, 262-275.

Hilson, G., 2003. Defining "cleaner production" and "pollution prevention" in the mining context. Min. Eng. 16, 305-321.
Lundstedt, T., Seifert, E., Abramo, L., Theilin, B., Nyström, A., Pettersen, J. Bergman, R., 1998. Experimental design and optimization. Chemom. Intell. Lab. 42, 3-42.

Martins, A.H., Resende, P.C., Barrado, F.S., 1999. Sulfuric activation of a Brazilian manganese ore for heavy metals removal. Hydrometallurgy 51, 325-333.

Martins, A.H., Carvalhinho, C.A., Pedrosa, M.F., 2001. Extração por solventes aplicada à remoção de metais pesados presentes no licor de lixiviação do minério de manganês da Mina do Azul (PA). Rev. Esc. Minas. 3.

Momade, F.W.Y., 1996. Sulphuric acid leaching of the Nsuta manganese carbonate ore. Hydrometallurgy 40, 123-134.

Nayl, A.A., Ismail, I.M., Aly, H.F., 2011. Recovery of pure $\mathrm{MnSO}_{4} \cdot \mathrm{H}_{2} \mathrm{O}$ by reductive leaching of manganese from pyrolusite ore by sulfuric acid and hydrogen peroxide. Int. J. Min. Process 100, 116-123.

Ngah, W.S.W., Ghani, S.A., Kamari, A., 2005. Adsorption behaviour of Fe(II) and $\mathrm{Fe}(\mathrm{III})$ ions in aqueous solution on chitosan and cross-linked chitosan beads. Bioresour. Technol. 96, 443-450.

Paixão, J.M.M., Amaral, J.C., Memória, L.E., Freitas, L.R., 1995. Sulphation of Carajás manganese ore. Hydrometallurgy 39, 215-222.

Shaheen, W.M., Selim, M.M., 1998. Effect of thermal treatment on physicochemica properties of pure and mixed manganese carbonate and basic copper carbonate. Thermochim. Acta 322, 117-128.

Sharma, T., 1992. Physico-chemical processing of low grade manganese ore. Int. J Min. Process 35, 191-203.

Zhang, W., Cheng, C.Y., Pranolo, Y., 2010. Investigation of methods for removal and recovery of manganese in hydrometallurgical processes. Hydrometallurgy 101 $58-63$. 